\title{
Gravide med polycystisk ovarie-syndrom bør følges nøye
}

\section{Kvinner med polycystisk ovarie-syndrom har økt risiko for svanger- skapskomplikasjoner, uavhengig av om de har fått fertilitetsbehandling eller ikke.}

Kvinner med polycystisk ovarie-syndrom og som er infertile, får oftere svangerskapsrelaterte komplikasjoner. En nylig publisert svensk studie viser at dette også gjelder de som ikke har fătt fertilitetsbehandling (1).
Av alle enkeltfødsler i Sverige i perioden 1995-2007 var 3787 fødsler av kvinner med dette syndromet og nesten 1,2 millioner av kvinner uten. Polycystisk ovarie-syndrom var assosiert med svangerskapsdia-

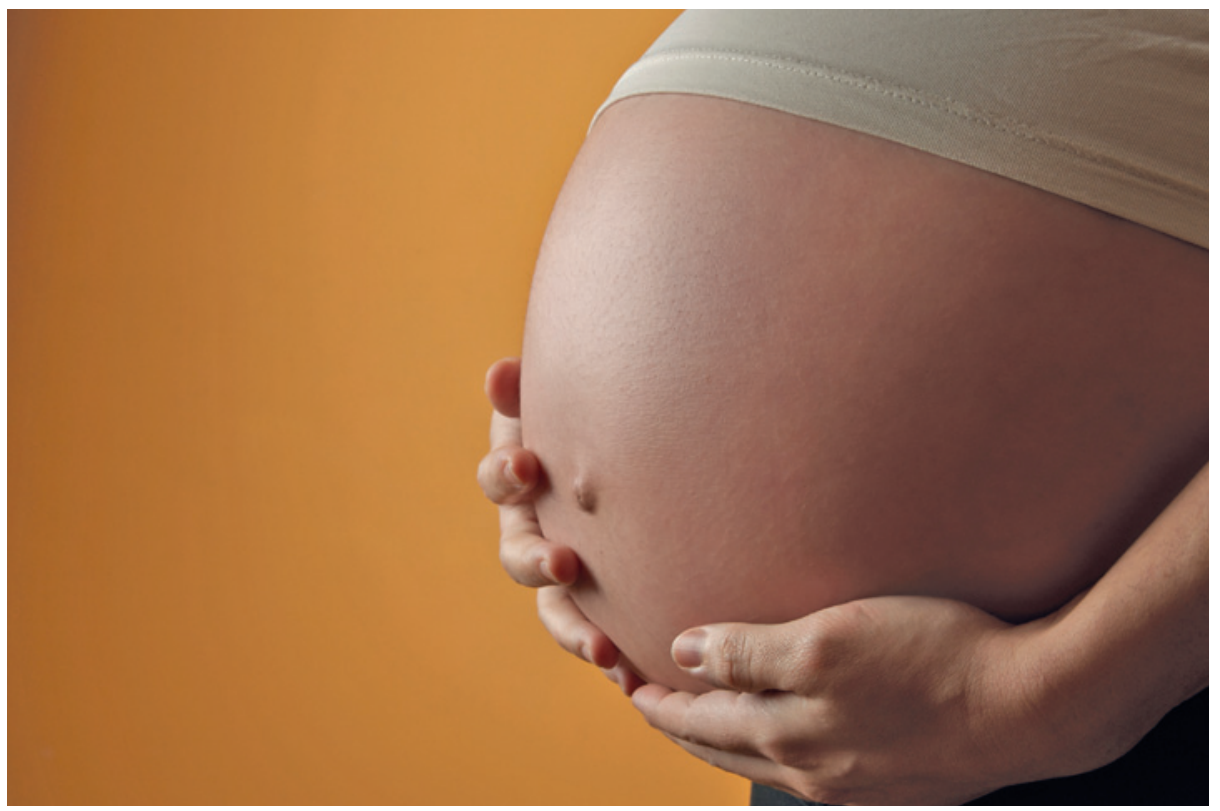

betes, preeklampsi og ekstremt for tidlig fødsel (oddsratio henholdsvis 2,32, 1,45 og 2,21 justert for bl.a. overvekt og høy fødselsalder). Barn av slike mødre hadde økt risiko for lav apgarskår og mekoniumaspirasjon og for å være stor for svangerskapsalder (large for gestational age, LGA) (justert oddsratio 1,41, 2,02 og 1,39). Forfatterne mener at kvinner med slikt syndrom bør følges opp tettere enn andre kvinner under svangerskap.

- Dagens anbefalinger for spesialoppfølging under graviditet er mer uklare for polycystisk ovarie-syndrom enn for enkeltdiagnoser som bl.a. epilepsi og diabetes, sier gynekolog Sverre Sand i Oslo. - Dette beror nok delvis på at disse pasientene tilhører en heterogen gruppe, og at det ikke er avklart hvordan syndromet skal behandles optimalt.

En svakhet med studien er at den ikke har kunnet identifisere kvinner med polycystisk ovarie-syndrom uten erkjent diagnose. Det betyr at det er uavklart hvor stor spredningen $i$ risiko er innad blant pasientene Det kreves mer kunnskap for å kunne selektere dem som trenger spesiell oppfølging, sier Sand.

\section{Linn Bernklev}

linnbernklev@hotmail.com

Oslo

\section{Litteratur}

1. Roos N, Kieler H, Sahlin L et al. Risk of adverse pregnancy outcomes in women with polycystic ovary syndrome: population based cohort study. BMJ 2011: 343: d6309.

\section{Interessekonflikter og kliniske retningslinjer}

\section{Mange av dem som utarbeider \\ kliniske retningslinjer har \\ interessekonflikter og unnlater \\ å rapportere om dem.}

Interessekonflikter, særlig økonomiske, er problematiske, både ved studier og ved utarbeiding av retningslinjer for klinisk praksis. Nå har amerikanske forskere kartlagt økonomiske interessekonflikter blant medlemmer av paneler som utarbeider retningslinjer for screening og behandling av hyperlipidemi og diabetes (1).

Retningslinjer publisert av nasjonale organisasjoner i USA og Canada mellom 2000-10 ble gjennomgått. Fem av de 14 rele- vante sett med retningslinjer som ble funnet, inneholdt ingen opplysninger om interessekonflikter for panelmedlemmene. 150 av til sammen 288 panelmedlemmer hadde interessekonflikter, hvorav 138 hadde opplyst om dem, mens 12 ikke hadde opplyst om dem. Av 73 medlemmer som hadde oppgitt at de ikke hadde interessekonflikter, ble slike likevel påvist hos åtte. Halvparten av panellederne hadde økonomiske interessekonflikter.

- Vi har sett det samme problemet i Norge, sier Ole Frithjof Norheim, som er professor i medisinsk etikk ved Universitetet i Bergen. I Helsedirektoratets retningslinjer for primærforbygging av hjerte- og karsykdommer, oppga åtte av faggruppens ti medlemmer mulige interessekonflikter. Det betyr ikke at alle var reelle, men at det kunne oppfattes slik.
Selv var jeg overrasket over at så mange hadde mulige bindinger til industrien, sier Norheim, som var leder for faggruppen.

- Vi valgte å gjøre åpent rede for mulige interessekonflikter og gjorde dem kjent for Helsedirektoratets ledelse på forhånd. Åpenhet og transparens er et minimum for å redusere tap av legitimitet, sier Norheim.

\section{Trine B. Haugen}

trine.b.haugen@hf.hio.no

Tidsskriftet

\section{Litteratur}

1 Neuman J. Korenstein D, Ross JS et al. Prevalence of financial conflicts of interest among panel members producing clinical practice guidelines in Canada and United States: cross sectional study. BMJ 2011; 343: d5621. 